\title{
ACRL honors the 2002 award winners
}

\section{Recognizing professional achievement}

by Mary Jane Petrowskì and Stephanie Sherrod

\section{Excellence in Academic Libraries winners}

The winners of the 2002 Excellence in Academic Libraries Award are the Andrew G. Truxal Library at Anne Arundel Community College, Cornell University Library, and Oberlin College Libraries.

Sponsored by ACRL and Blackwell's Book Services, the award recognizes the staff of a community college, a college, and a university library for programs that deliver exemplary services and resources to further the educational mission of the institution.

"Receiving an Excellence in Academic Libraries Award is a national tribute to a library for the outstanding services, programs, and leadership it provides to its staff, faculty, and community," said Mary Ellen Davis, ACRL executive director.

\section{The Andrew G. Truxal Library at Anne Amundel Community College}

The Andrew G. Truxal Library at Anne Arundel Community College, winner in the community college category, emphasized its unique strategies for meeting the needs of the student body as well as its creative information literacy program that supports the curriculum.

Larry Hardesty, chair of the 2002 Excellence in Academic Libraries Selection Committee, said, "The selection committee felt that the library's emphasis on 'colleagues in learning' gave new meaning to the concept of a learning community."

"I am thrilled that the faculty and staff at Anne Arundel Community College's Andrew G. Truxal Library have won the Excellence in Academic Libraries

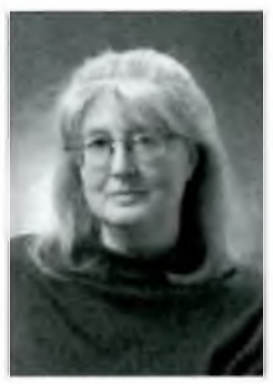

Cynthia K. Steinhoff Award," said Library Director Cynthia K. Steinhoff.

"This prestigious honor signifies that our library colleagues recognize our firm commitment to student success and lifelong learning. Our partnerships with the faculty, administrators, and others on campus made possible this high level of student support, and I salute them for the vital role they continue to play in helping our library be the best it can be."

\section{Cornell University Library}

Cornell University Library described its commitment to staff development and transforming scholarly communication in its winning application in the university category. Hardesty and the selection committee commented, "Cornell University Library undertook ambitious digitization projects and was will-

\section{About the authors}

Mary Jane Petrowski is ACRL senior associate executive director, e-mail: mpetrowski@ala.org, and Stephanie Sherrod is ACRL program assistant, e-mail: ssherrod@ala.org 


\section{Phipps named Academid/Research Librarian of the Year}

Shelley E. Phipps, assistant dean for team and organization development at the University of Arizona (UA) Library in Tucson, Arizona, is the 2002 ACRL Academic/Research Librarian of the Year. The award, sponsored by YBP Library Services, recognizes an outstanding member of the library profession who has made a significant national or intemational contribution to academic research librarianship and library development.

In announcing its selection, the award committee commended Phipps' visionary leadership, noting, "Shelley was one of the first to signal a need to transform our libraries to become organizations that will meet the challenges of the 21st century. She has facilitated significant change at the University of Arizona Library and in numerous other libraries where she has served as a consultant. Shelley's commitment to teaching and mentoring has created an endur-
Shelley E. Phipps and staff of the University of Arizona Library in Tucson, Arizona.

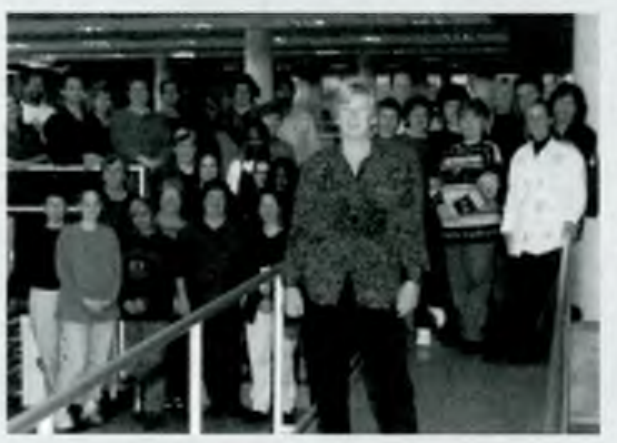

Governor's Award for Excellence in 1996. Most recently, she contributed her leadership skills to the ACRL Board planning process by facilitating the development of the 2005 ACRL Strategic Plan.

Phipps is a highly regarded organizational development consultant. In 1977, she was selected as a Council of Library Resources academic library management intern, serving in the Duke University Perkins Library. In 1981, she graduated from the ARL Consultant Training Program. Her work with the ARL Library Management Skills Institutes, the Leadership and Career Development Program, and the New Measures Program, has contributed directly to the professional development of hundreds of academic librarians.

Phipps also played a critical role in the transformation of the service model at UA.

Phipps' publications reflect her pioneering work in the area of organizational change and leadership. Her most recent publiing legacy that will continue to touch and influence the development of academic librarianship for years to come. Most importantly, her accomplishments demonstrate that an academic librarian can be a visionary and influential leader without holding the director's position."

"I was really surprised when Mary Reichel called to congratulate me," said Phipps. "I'm not someone who does much of anything by myself. I am always collaborating with others and learning from others. I view this as an award for teamwork, for being willing to be involved, for sharing what I am learning, and for assuming shared leadership for the development of libraries, librarians, and the library profession."

Phipps has held key national leadership positions, serving on the ACRL Board of Directors from 1990-1994, chairing both the ACRL University Libraries Section in 1985 and the ACRL Bibliographic Instruction Section in 1981. The State of Arizona awarded Phipps the cations are "Beyond Measuring Service Quality: Learning from the Voices of the Customers, the Staff, the Processes, and the Organization" ( $\mathrm{Li}$ brary Trends, Spring 2000) and "Transforming Libraries into Learning Organizations: The Challenge for Leadership" (Catahs's for Change: Managing Libraries in the 1990s, 1993). Her 1993 publication has become a touchstone for those who want to learn how to transform their libraries.

Phipps received her bachelor's in English literature from Regis College and earned her MLS from UA. At the UA Library she has served as assistant dean for team facilitation since 1993 , assistant university librarian for branch services (1991-1993), and held other positions, including acting university librarian, assistant university librarian for branch services, and head librarian for the UA Science-Engineering Library.

Phipps will receive a cash award of $\$ 3,000$ and a citation at a ceremony and reception to be held Monday, June 17, 2002 during the ALA Annual Conference in Atlanta. The reception is sponsored by YBP Library Services. 


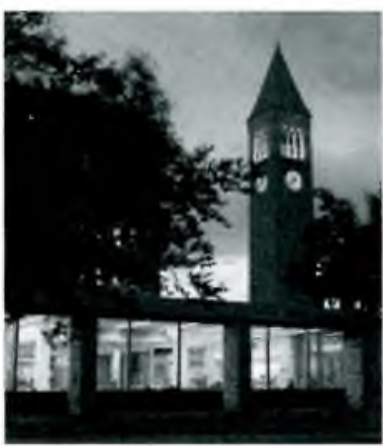

Cornell University Library ing to share lessons learned with the wider higher education community."

Sarah E. Thomas, Carl A. Kroch university librarian at Cornell University Library, said,
"We are delighted to have been selected. You can't imagine what a wonderful place Cornell is until you've had the pleasure of spending time with our creative and dedicated library staff. They have an unparalleled esprit de corps, working together to bring the highest quality service to Cornell students, faculty, and staff.

"Whether building a cutting-edge digital library, providing a nutturing and intellectual environment for cam-

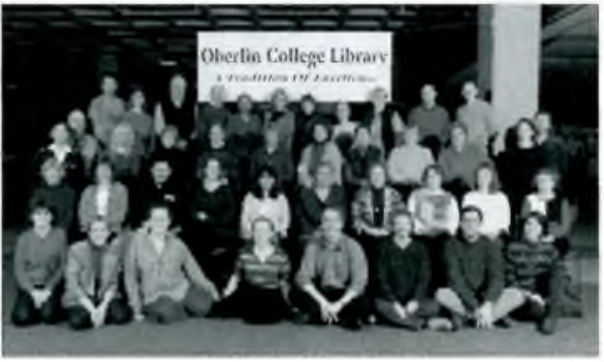

Staff at the Oberlin College Libraries.

\section{Oberlin College Libraries}

The Oberlin College Libraries, winner in the college category, was commended by the selection committee for "a tradition of leadership excellence, both on campus and in the profession." The committee also saluted Oberlin for its model program aimed at recruiting student library assistants into academic librarianship.

"Winning the award is a testament to the superb quality of our library staff and their ongoing commitment to providing excellent services and resources for our community. I greatly appreciate the opportunity this award provides to celebrate the staff's many recent accomplishments, which are part of a long tradition of library excellence at Oberlin," said Ray English, director of libraries at Oberlin College.

Each winning library will receive $\$ 3,000$ and a citation, to be presented at an award ceremony held on each recipient's campus. The winners will also receive special recognition at the $\mathrm{ACRL}$ pus learners, or sharing their research with others, my colleagues are the best."
President's Program during the AlA Annual Conference on June 17, 2002, in Atlanta.

\section{Instruction for first-year undergraduates: Developing strategies to facilitate their transitions}

Please join ACRL's Instruction Section for a preconference in Atlanta, June 14, 2002. The topic of the preconference, Instruction for First-Year Undergraduates: Developing Strategies to Facilitate Their Transitions, is an exciting one!

This preconference will explore characteristics of first-year students, examine what they are learning about information resources and strategies in high school, and investigate programmatic innovations at the institutional and library levels that meet first-year student needs. During the interactive preconference, atrendees will develop or enhance personal instructional approaches to working with first-year students with leadership from highly respected librarians.
The speakers include: Randy Hensley, University of Hawaii at Manoa; Frances Jacobson, University of Illinois at UrbanaChampaign; Lisa Janicke Hinchliffe, Illinois State University; and Margit Watts, University of Hawaii at Manoa.

This conference topic was hugely successful at ALA's Annual Conference in Chicago. If you missed it or want a refresher, please join us in Atlanta.

Registration information is now available, and location information will be available shortly. Seating is limited, so please mark your calendars now for June 14, 2002 and plan to attend. Questions? Please contact Carla Wilson Buss, University of Georgia, at (706) 542-1114 or cbuss@libris.libs.uga.edu. See you in Atlanta! 


\section{Get ahead,}

\section{take control.}

Swets Blackwell is there to help you take control of the complex and time-consuming processes involved in managing electronic content. From rapid set-up of electronic subscriptions to full integration with library management and e-procurement systems and advanced article delivery solutions, we can help.

Our sophisticated aggregator service enables speedy delivery of several thousand e-titles from a multitude of prestigious publishers right to your desktop. Want to learn more? Visit us at www.swetsblackwell.com/ejs

Swets Blackwell

160 Ninth Avenue, P.O. Box 1459 Runnemede, NJ 08078

T: 800-645-6595 • F: 856-312-2000

www.swetsblackwell.com

\section{Sivets Blackwell}

